\title{
ANNOUNCEMENTS
}

Research on the Church of the East in China and Central Asia Salzburg, June 4-9, 2009

\section{First Announcement}

The 3rd International Conference "Research on the Church of the East in China and Central Asia" will be held at the Conference Center St. Virgil in Salzburg, Austria, June 4-9, 2009.

GENERAL PROGRAM:

June 4, 2009: Opening Session at 7.00pm

June 5-8, 2009: Conference sessions

June 9, 2009: Departure after breakfast

There will be an organised excursion and an evening concert.

\section{PAPERS}

We welcome papers from disciplines such as Philology, Archaeology, Sinology, Syrology, History, Theology/Religious Studies, Cultural and Asian Studies to explore and discuss various aspects of the Church of the East ("Nestorian" or East Syriac Christianity) in China and Central Asia. A small number of papers on East Syriac Christianity in India or other areas in Asia may also be accepted. Papers should be original, concise and to the point. They should take 20 minutes to deliver and be presented in English.

\section{PROCEEDINGS}

Proceedings will be published. Participants will be informed about the publication guidelines during the conference. Papers presented at the 1st conference (2003) were published in: Jingiiao: The Church of the East in China and Central Asia. Ed. by Roman Malek in connection with Peter Hofrichter. (Sankt Augustin: Institut Monumenta Serica, 2006) ISBN 3-8050-0534-2. The publication of the 2nd conference papers (2006) is forthcoming in fall 2008.

Dietmar W. Winkler

Fachbereich Bibelwissenschaft und Kirchengeschichte

Universität Salzburg

Universitätsplatz 1, A-5020 Salzburg, Austria

Tel. +43 662842521 142; Fax: +43662842521 143 